\title{
Efficacy of Nutritional Interventions on Inflammatory Markers in Haemodialysis Patients: A Systematic Review and Limited Meta-Analysis
}

\author{
Ban-Hock Khor ${ }^{1}$, Sreelakshmi Sankara Narayanan ${ }^{1}$, Sharmela Sahathevan ${ }^{1}$, \\ Abdul Halim Abdul Gafor ${ }^{2}$, Zulfitri Azuan Mat Daud ${ }^{3}$ (D), Pramod Khosla ${ }^{4}$, Alice Sabatino 5 (D), \\ Enrico Fiaccadori ${ }^{5}$, Karuthan Chinna ${ }^{6}$ and Tilakavati Karupaiah ${ }^{1,7, *}$ \\ 1 Dietetics Program, Faculty of Health Sciences, Universiti Kebangsaan Malaysia, Kuala Lumpur 50300, \\ Malaysia; khorbanhock@gmail.com (B.-H.K.); sreelakshmiprem07@gmail.com (S.S.N.); \\ sham_0901@yahoo.com (S.S.) \\ 2 Department of Medicine, Faculty of Medicine, Universiti Kebangsaan Malaysia, Kuala Lumpur 56000, \\ Malaysia; halimgafor@gmail.com \\ 3 Department of Nutrition and Dietetics, Faculty of Medicine and Health Sciences, Universiti Putra Malaysia, \\ Selangor 43400, Malaysia; zulfitri@upm.edu.my \\ 4 Department of Nutrition \& Food Sciences, College of Liberal Arts \& Sciences, Wayne State University, \\ Detroit, MI 48202, USA; aa0987@wayne.edu \\ 5 Acute and Chronic Renal Failure Unit, Department of Clinical and Experimental Medicine, \\ University of Parma, 43126 Parma, Italy; alice.sabatino86@gmail.com (A.S.); enrico.fiaccadori@unipr.it (E.F.) \\ 6 Department of Social and Preventive Medicine, Faculty of Medicine, University of Malaya, \\ Kuala Lumpur 50603, Malaysia; karuthan@gmail.com \\ 7 School of BioSciences, Faculty of Health and Medical Sciences, Taylor's University, \\ Subang Jaya 47500, Malaysia \\ * Correspondence: tilly_karu@yahoo.co.uk
}

Received: 8 February 2018; Accepted: 21 March 2018; Published: 23 March 2018

\begin{abstract}
Low-grade chronic inflammation is prevalent in patients undergoing haemodialysis (HD) treatment and is linked to the development of premature atherosclerosis and mortality. The non-pharmacological approach to treat inflammation in HD patients through nutritional intervention is well cited. We aimed to assess the efficacy of different nutritional interventions at improving inflammatory outcomes in HD patients, based on markers such as C-reactive protein (CRP), interleukin-6 (IL-6), and tumour necrosis factor- $\alpha$ (TNF- $\alpha$ ). We searched PubMed, Cochrane Library, and Embase for randomized controlled trials (RCT) published before June 2017. Inclusion criteria included RCTs on adult patients on maintenance HD treatment with duration of nutritional interventions for a minimum 4 weeks. Risk of bias was assessed using the Jadad score. In total, 46 RCTs experimenting different nutritional interventions were included in the review and categorized into polyphenols rich foods, omega- 3 fatty acids, antioxidants, vitamin D, fibres, and probiotics. Meta-analyses indicated significant reduction in CRP levels by omega- 3 fatty acids (Random model effect: $-0.667 \mathrm{mg} / \mathrm{L}, p<0.001$ ) and vitamin $\mathrm{E}$ (fixed model effect: $-0.257 \mathrm{mg} / \mathrm{L}$, $p=0.005)$. Evidence for other groups of nutritional interventions was inconclusive. In conclusion, our meta-analysis provided evidence that omega- 3 fatty acids and vitamin E could improve inflammatory outcomes in HD patients.
\end{abstract}

Keywords: haemodialysis; nutrition; inflammation; antioxidants; omega-3 fatty acids; polyphenols; fibres; systematic review; meta-analysis 


\section{Introduction}

Haemodialysis (HD) patients experience a 3 to 4 times a higher mortality rate compared to their peers without chronic kidney disease (CKD). Cardiovascular disease (CVD) is cited as the main cause of mortality [1]. Epidemiological studies show that traditional CVD risk factors such as obesity, hypercholesterolemia, and high blood pressure exhibit paradoxical relationships with mortality risk in this population [2,3]. Chronic low-grade inflammation is a major contributing factor to the pathogenesis of atherosclerosis and has been reported in 30 to $50 \%$ of HD patients [4]. Acute inflammation is an adaptive response towards injury and infection, but a dysregulated on-going inflammatory state detrimentally affects the physiological process [5]. Particularly, chronic systemic inflammation in HD patients as indicated by increased levels of inflammatory markers such as C-reactive protein (CRP) and interleukin-6 (IL-6) are strong predictors for CVD and overall mortality [6,7]. Inflammation per se also contributes to the early development of co-morbid conditions such as protein energy wasting, vascular calcification, endocrine disorders, and depression, which vastly decrease the quality of life in HD patients [8,9].

Patients undergoing HD treatment may experience inflammation triggered by both endogenous and exogenous factors. Elevations of CRP and IL-6 levels have been documented in CKD patients even before initiation of HD [10]. The HD procedure itself is directly involved in triggering the inflammatory response by (i) passage of endotoxin from the dialysate to the circulation [9]; (ii) filter membrane bio-incompatibility [11]; (iii) use of a central dialysis catheter [12]; and (iv) non-ultrapure dialysate use [13]. Other contributory factors to inflammation include fluid overload, persistent infections, and periodontal disease [9]. HD patients also experience elevated oxidative stress levels from increased production of reactive oxygen species (ROS) and reduction in antioxidant defences [14]. The relationship between inflammation and oxidative stress is bidirectional and synergic [15]. Oxidative stress invokes inflammation via activation of nuclear factor kappa B (NF- $\mathrm{kB}$ ), a transcription factor that regulates inflammatory responses with HD patients experiencing higher NF-кB gene expression compared to their healthier counterparts $[15,16]$. Recently, the gut has been identified as a potential source of inflammation. In CKD patients, the gut microbiome milieu shifts towards favouring the growth of bacteria with urease and co-enzymes generating uremic toxins such as $p$-cresyl and indoxyl sulfates. Translocation of these substances from the gut into the blood compartments induces systemic inflammation as occurs in the case of translocation of living bacteria due to intestinal barrier disruption $[17,18]$.

Since persistent inflammation is a major contributory factor to morbidity and mortality in HD patients, it is identified as a potential target of treatment to improve outcomes. Drugs commonly prescribed to HD patients such as statins, angiotensin-converting-enzyme inhibitor, and angiotensin receptor blockers with pleiotropic anti-inflammatory effects, as well as novel targeted anticytokine treatments, have been suggested as potential therapies to treat inflammation in HD patients [19]. There is also a growing interest in exploring the therapeutic effects of dietary components with immune modulating properties. In fact, modifiable risk factors such as cultural habits and dietary intake may explain discrepancies in CRP levels in HD patients across different nations reported in The Dialysis Outcomes and Practice Patterns Study [6,20]. As the evidence of nutritional interventions in reducing inflammation biomarkers in HD patients is accumulating, we therefore adopted the systematic review approach to identify potential nutritional interventions and examine their efficacy as the anti-inflammatory therapeutic agents for HD patients.

\section{Materials and Methods}

\subsection{Data Sources, Searches, and Selection}

We searched the following database through June 2017: PubMed, Embase, and Cochrane Library to identify all published randomized controlled trials (RCTs) for nutritional intervention in maintenance HD patients that listed inflammatory outcomes. We used "hemodialysis/haemodialysis" 
AND ("omega-3 fatty acids" OR "alpha-linolenic acids" OR "flaxseed" OR "selenium" OR "vitamin E" OR "tocopherols" OR "tocotrienols" OR "vitamin C" OR "ascorbic acids" OR "antioxidants" OR "alpha-lipoic acids" OR "vitamin D" OR "flavonoids" OR "isoflavones" OR "soy protein" OR "cathechins" OR "green tea" OR "pomegranate" OR "fiber" OR "prebiotics" OR "probiotics") as the search terms. Citations of studies identified were exported to EndNote version X7.5.3. Two authors (B.H.K. and S.S.N.) independently reviewed the titles and abstracts, and full texts of potential studies were retrieved for further appraisal. In case of disagreement between the two authors, a third author (T.K.) was referred. We also performed a manual search for eligible studies by checking the reference lists of relevant original and review articles.

We included eligible studies meeting these criteria: (i) published randomized controlled (parallel arm and crossover) trials in adult end stage renal disease (ESRD) patients ( $\geq 18$ years old) undergoing maintenance HD; (ii) comparing nutrition interventions with a placebo or blank control; (iii) at least a 4-week follow up; (iv) reporting at least one of these inflammatory outcomes: either C-reactive protein (CRP) or high sensitivity CRP (hsCRP), interleukin-6 (IL-6), and tumour necrosis factor- $\alpha$ (TNF- $\alpha$ ); and (v) English language publications. We excluded (i) studies on paediatric patients, pre-dialysis CKD patients, acute kidney injury patients, ESRD patients with other renal replacement therapy modalities such as peritoneal dialysis and transplant; (ii) studies with provision of nutrition intervention via injection, intravenous route, topical, or dialyzer; (iii) single arm, cross-sectional or prospective studies; and (iv) case reports, conference proceedings, review articles, editorials, and letters.

\subsection{Quality Assessment}

Two authors (B.H.K. and S.S.N.) performed the quality assessment of studies included in this systematic review using the Jadad scale [21]. Based on the study design such as randomization and blinding, as well as withdrawals and dropouts, each study was rated with a score ranging from 0 to 5 , and studies with Jadad score above 3 were considered high quality.

\subsection{Statistical Analysis}

A meta-analysis was planned whenever a minimum 3 studies with similar nutrition interventions were available. Studies were excluded from the meta-analysis when data could not be retrieved from the manuscript or when there was a lack of response from primary authors contacted for critical data for such manuscripts. Two meta-analyses were performed to test the effects of omega- 3 fatty acids supplementation and vitamin E supplementation on CRP, respectively. Extractable data for each study was tabulated. Standard mean difference (SMD) and 95\% confidence intervals (CIs) were calculated from sample size, pre- and post-mean, and standard deviation changes for both intervention and control groups. $I^{2}$ statistic was used to assess the heterogeneity between study results in meta-analyses, and $I^{2}$ above $75 \%$ was considered as high heterogeneity. In the presence of heterogeneity, the random effect model was used to pool data from relevant studies. STATA software (version 12.0, StataCorp, College Station, TX, USA) was used for the analyses.

\section{Results}

Forty-six studies out of 186 studies (Table S1) met the inclusion criteria (Figure 1). Table 1 summarises the characteristics of studies included for this review. The nutrition interventions were categorized into 6 main groups: (i) polyphenols [22-29]; (ii) omega-3 fatty acids [30-42]; (iii) antioxidants [39,43-55]; (iv) vitamin D [56-59]; (v) fibre and probiotics [60-63]; and (vi) combinations of more than one type of nutrition intervention [39,47,64-67]. Two studies included had 3 intervention arms [39,47]. Forty-four studies were randomized parallel studies and 2 were randomized crossover studies. The sample size ranged from 10 to 325 patients and only 8 studies had total sample size above 100 patients $[25,29,38,40,44,59,62,66]$. The study duration ranged from one to 12 months. However, only one study lasted 12 months [25], while others were 6 months or below. Seventeen studies originated from North America, 15 from Middle East, 7 from Europe, 
5 from Asia, and 2 from South America. CRP was reported in 44 studies, whereas IL- 6 and TNF- $\alpha$ were reported in 19 and 9 studies, respectively. As per the Jadad scoring [21] to rate quality of these studies, one study [23] had a score of 1,10 studies [24,41,43-45,47,52-54,62] scored 2, 9 studies [22,33,35,49,55,57,60,61,65] scored 3,12 studies [25,26,28,29,32,34,36,40,46,50,51,67] scored 4, and 14 studies $[27,30,31,37-39,42,48,56,58,59,63,64,66]$ scored 5 .

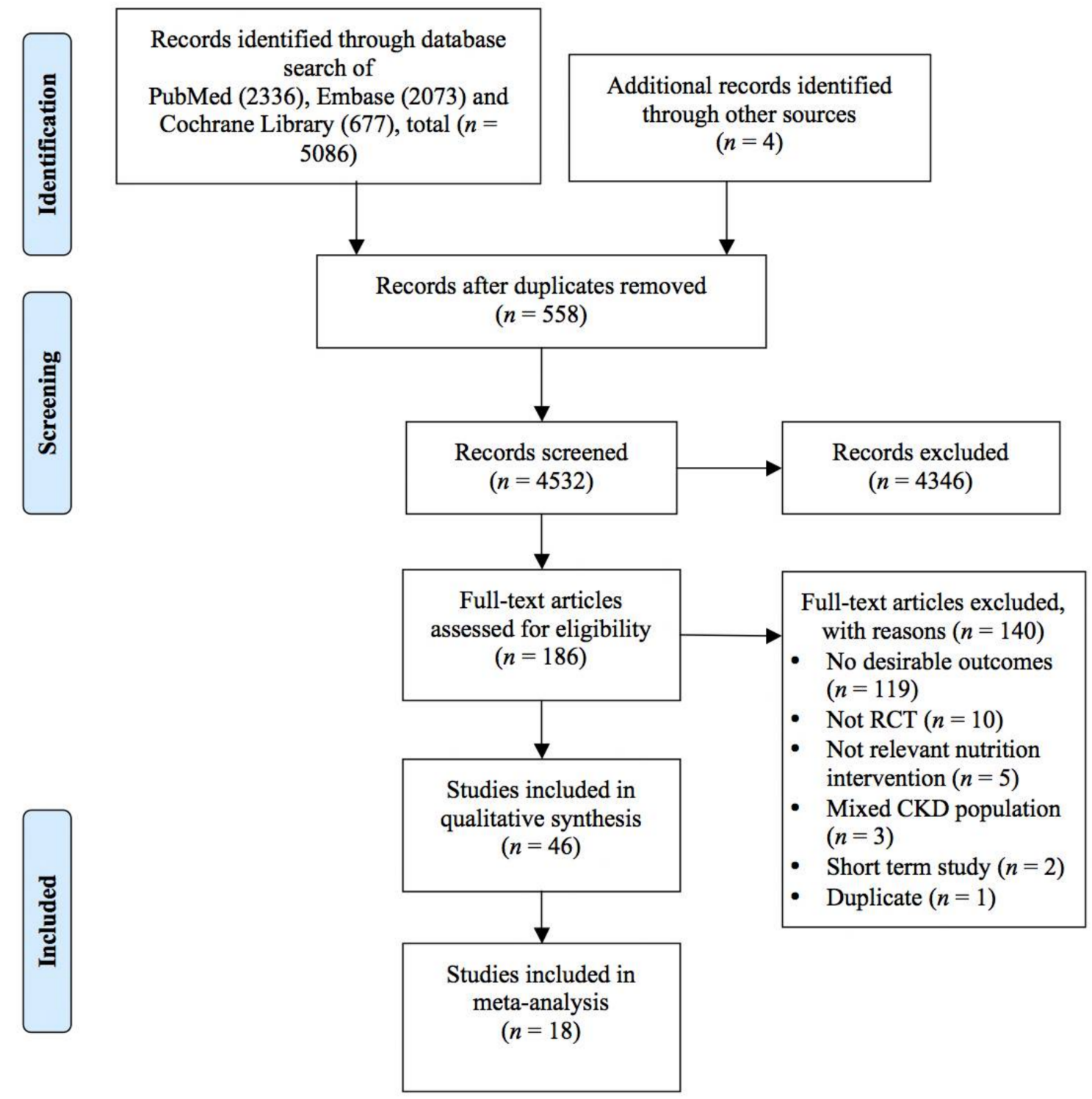

Figure 1. Preferred Reporting Items for Systematic Reviews and Meta-Analyses (PRISMA) study flow for literature search and trials selection process. Abbreviation: RCT, randomized controlled trials; CKD, chronic kidney disease. 
Table 1. Characteristics of randomized controlled trials categorized by groups.

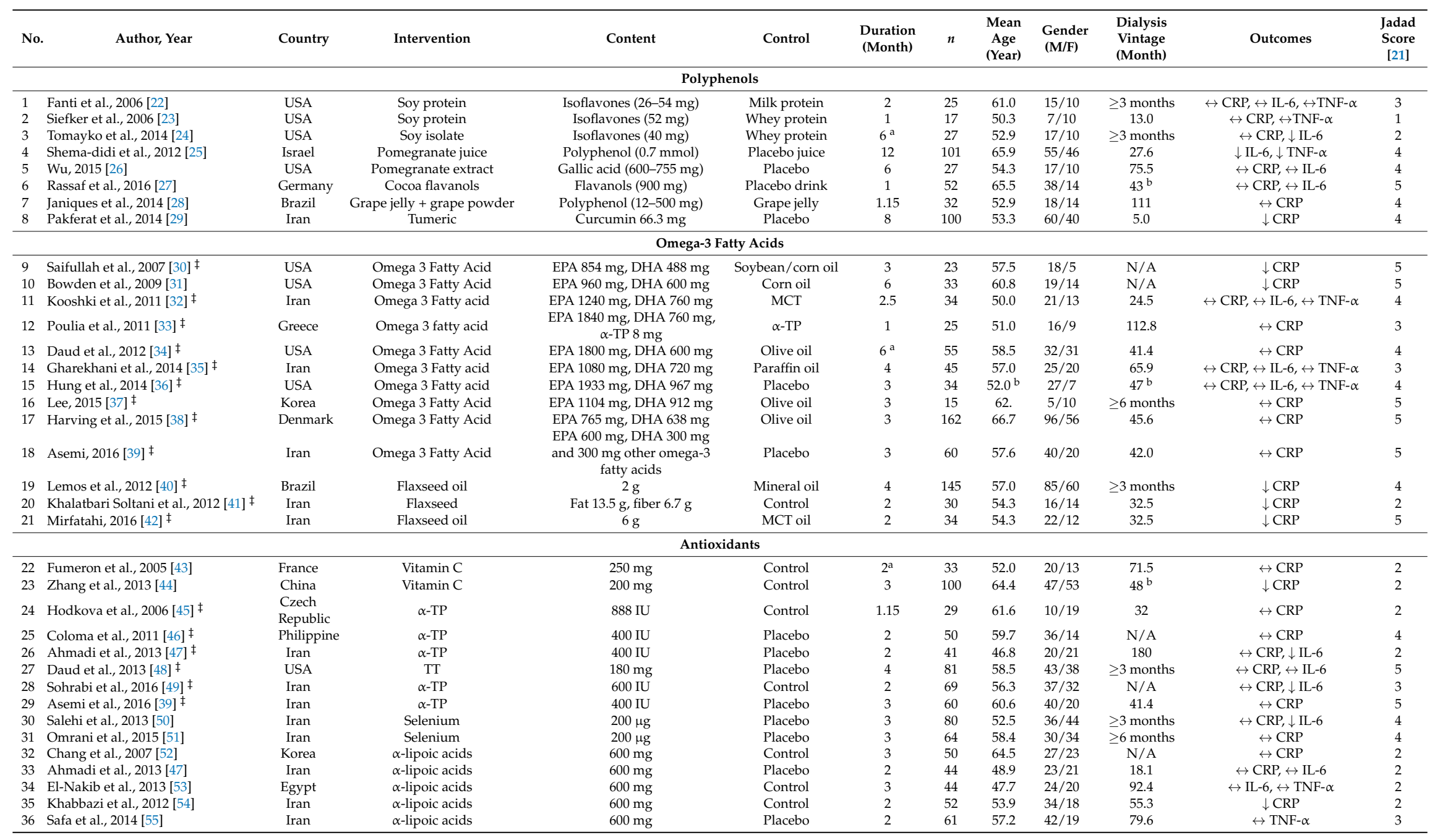


Table 1. Cont.

\begin{tabular}{|c|c|c|c|c|c|c|c|c|c|c|c|c|}
\hline No. & Author, Year & Country & Intervention & Content & Control & $\begin{array}{l}\text { Duration } \\
\text { (Month) }\end{array}$ & $n$ & $\begin{array}{l}\text { Mean } \\
\text { Age } \\
\text { (Year) }\end{array}$ & $\begin{array}{l}\text { Gender } \\
(\mathrm{M} / \mathrm{F})\end{array}$ & $\begin{array}{l}\text { Dialysis } \\
\text { Vintage } \\
\text { (Month) }\end{array}$ & Outcomes & $\begin{array}{c}\text { Jadad } \\
\text { Score } \\
\text { [21] }\end{array}$ \\
\hline \multicolumn{13}{|c|}{ Vitamin D } \\
\hline 37 & Marckmann et al., 2012 [56] & Denmark & Cholecalcife-rol & $40,000 \mathrm{IU}$ & Placebo & 2 & 27 & N/A & N/A & N/A & $\leftrightarrow \mathrm{CRP}, \leftrightarrow \mathrm{IL}-6$ & 5 \\
\hline 38 & Hung et al., 2013 [57] & USA & Paracalcitol & As per KDOQI guidelines & Cinacalcet & 2 & 10 & 48.5 & $6 / 4$ & $40^{\mathrm{b}}$ & $\leftrightarrow \mathrm{CRP}, \leftrightarrow \mathrm{IL}-6$ & 3 \\
\hline 39 & Seibert et al., 2013 [58] & Germany & Cholecalcife-rol & $20,000 \mathrm{IU}$ & Placebo & 3 & 33 & 67.2 & $18 / 15$ & 25.2 & $\leftrightarrow \mathrm{CRP}, \leftrightarrow \mathrm{TNF}-\alpha$ & 5 \\
\hline 40 & Miskulin et al., 2016 [59] & USA & Ergocalcife-rol & $50,000 \mathrm{IU}$ & Placebo & 6 & 252 & 61.1 & N/A & $42^{\mathrm{b}}$ & $\leftrightarrow \mathrm{CRP}$ & 5 \\
\hline \multicolumn{13}{|c|}{ Fibers \& Probiotics } \\
\hline 41 & Sirich et al., 2014 [60] & USA & High amylose corn starch & $15 \mathrm{~g}$ & Waxy corn starch & 1.4 & 40 & 56.0 & $24 / 16$ & 48.0 & $\leftrightarrow \mathrm{CRP}$ & 3 \\
\hline 42 & Natarajan et al., 2014 [61] & USA & Probiotics & $\begin{array}{l}\text { S. thermophilus KB 19, L. acidophilus KB } \\
27 \text {, and B. longum } \mathrm{KB} 31\left(3 \times 10^{9} \mathrm{CFU}\right)\end{array}$ & $\begin{array}{l}\text { Cream of } \\
\text { wheat and } \\
\text { psyllium husk }\end{array}$ & 2 & 22 & 54 & $6 / 16$ & N/A & $\leftrightarrow \mathrm{CRP}$ & 3 \\
\hline 43 & Xie et al., 2015 [62] & China & Water soluble fiber & $10 \mathrm{~g}$ and $20 \mathrm{~g}$ & Placebo starch & 1.5 & 124 & 52.8 & $68 / 56$ & 22.6 & $\downarrow \mathrm{CRP}, \downarrow$ IL- $6, \downarrow$ TNF- $\alpha$ & 2 \\
\hline 44 & Soleimani et al., 2016 [63] & Iran & Probiotics & $\begin{array}{l}\text { L. acidophilus, L. casei, and B. bifidum } \\
\qquad\left(2 \times 10^{9} \mathrm{CFU} / \mathrm{g} \text { each }\right)\end{array}$ & Placebo & 3 & 60 & 56.7 & $40 / 20$ & 42.6 & $\downarrow \mathrm{CRP}$ & 5 \\
\hline \multicolumn{13}{|c|}{ Nutrient Combinations } \\
\hline 45 & Himmelfarb et al., 2007 [64] & USA & $\gamma-\mathrm{TP}+\mathrm{DHA}$ & $\gamma$-TP $(308 \mathrm{mg})$ and DHA $(800 \mathrm{mg})$ & $\begin{array}{l}\text { High Oleic } \\
\text { Sunflower oil }\end{array}$ & 2 & 63 & 59.6 & $40 / 23$ & 28.1 & $\leftrightarrow \mathrm{CRP}, \downarrow \mathrm{IL}-6$ & 5 \\
\hline 46 & Kamgar et al., 2009 [65] & USA & Antioxidants & $\begin{array}{c}\text { Vitamin E }(800 \mathrm{IU}), \text { vitamin C } \\
(250 \mathrm{mg}), \mathrm{B} 6(100 \mathrm{mg}), \mathrm{B12}(250 \mu \mathrm{g}), \\
\text { and folic acid }(10 \mathrm{mg})\end{array}$ & Placebo & 2 & 37 & 52.1 & $22 / 15$ & 53.6 & $\leftrightarrow \mathrm{CRP}, \leftrightarrow \mathrm{IL}-6$ & 3 \\
\hline 47 & Ahmadi et al, 2013 [47] & Iran & Vitamin $E$ and $\alpha$-lipoic acids & $\begin{array}{l}\text { Vitamin E (400 IU) and } \alpha \text {-lipoic } \\
\text { acids (600 mg) }\end{array}$ & Placebo & 2 & 48 & 51.1 & $20 / 28$ & 17.7 & $\leftrightarrow \mathrm{CRP}, \downarrow \mathrm{IL}-6$ & 2 \\
\hline 48 & Himmelfarb et al., 2014 [66] & USA & Mixed TP and $\alpha$-lipoic acids & $\begin{array}{l}\text { Mixed TP (666 IU) and } \alpha \text {-lipoic } \\
\text { acids ( } 600 \mathrm{mg} \text { ) } \\
\text { L. acidophilus NCFM and }\end{array}$ & Placebo & 6 & 325 & 59.0 & $143 / 182$ & 51.5 & $\leftrightarrow \mathrm{CRP}, \leftrightarrow \mathrm{IL}-6$ & 5 \\
\hline 49 & Viramontes-Horner et al., 2015 [67] & Mexico & $\begin{array}{l}\text { Synbiotic gel, omega-3 fatty } \\
\text { acids, and vitamins }\end{array}$ & $\begin{array}{l}\text { Bifidobacterium lactis Bi-07 }\left(11 \times 10^{6}\right. \\
\text { CFU); inulin (2.31 g) EPA and DHA } \\
\text { (1.5 g); and vitamins (complex B, } \\
\text { folic acid, ascorbic acid, and vitamin E). }\end{array}$ & Placebo & 2 & 42 & 39.8 & $32 / 10$ & 60.3 & $\begin{array}{c}\leftrightarrow \mathrm{CRP}, \leftrightarrow \text { IL- } 6, \leftrightarrow \\
\text { TNF- } \alpha\end{array}$ & 4 \\
\hline 50 & Asemi et al., 2016 [39] & Iran & $\alpha$-TP, EPA, and DHA & $\begin{array}{l}\alpha \text {-TP (400 IU), EPA (600 mg), } \\
\text { and DHA (300 mg) }\end{array}$ & Placebo & 3 & 60 & 57.4 & $40 / 20$ & 40.8 & $\leftrightarrow \mathrm{CRP}$ & 5 \\
\hline
\end{tabular}

${ }^{a}$ Provided during dialysis day only; ${ }^{\mathrm{b}}$ median; symbols: $\leftrightarrow$ non significance $(p>0.05) ; \downarrow$ significant reduction $(p<0.05) ;{ }^{\ddagger}$ studies included for meta-analysis; Abbreviations: $\alpha$-TP, alpha tocopherol; CRP, C-reactive protein; DHA, docosahexaenoic acid; EPA, eicosapentaenoic acid; F, female; IL-6, interleukin-6; KDOQI, Kidney Disease Outcomes Quality Initiative; M, male; MCT, medium chain triglycerides; N/A, not available; TNF- $\alpha$, tumor necrosis factor alpha; TT, tocotrienols. 


\subsection{Polyphenols}

Polyphenol-rich nutrition interventions (total $n=381$, studies $=8$ ) used soy isoflavones (total $n=69$, studies $=3)$, pomegranate juices $(n=101)$ and extract $(n=27)$, cocoa flavanols $(n=52)$, turmeric powder $(n=100)$, and grape powder $(n=32$, study $=1)$. The large heterogeneity of polyphenol therapies did not allow for a formal meta-analysis. Comparing soy isoflavones to either milk or whey protein, all 3 studies reported no significant reduction in CRP levels [22-24], while one study reported significant reduction in IL-6 levels [24]. Shema-didi et al. [25] reported significant reduction in IL-6 and TNF- $\alpha$ levels after consumption of pomegranate juice for one year. Contrarily, another study $(n=27)$ reported that pomegranate extract consumption did not lead to significant reduction in both CRP and IL-6 levels [26]. Pokferat et al. [29] reported significant reduction in CRP levels after 8 weeks of turmeric powder supplementation. Two studies with the short intervention period ( $4-5$ weeks) examining the effects of cocoa flavanols [27] or grape powder [28] reported no significant reduction in CRP and IL-6 levels.

\subsection{Omega-3 Fatty Acids}

Thirteen studies investigated the effect of omega- 3 fatty acid supplementation on the reduction of inflammation in HD patients. Ten studies (total $n=486$ ) used eicosapentaenoic acid (EPA) and docosaahexanoic acid (DHA) from fish oil, while 3 studies (total $n=209$ ) used alpha-linolenic acid (ALA) from flaxseed oil. The dosage of EPA and DHA ranged between 600 to $1933 \mathrm{mg} /$ day and 300 to $967 \mathrm{mg} /$ day, respectively. Two studies [30,31] comparing EPA and DHA to corn oil or soybean oil reported significant reduction in CRP levels. Contrarily, 8 studies [32-39] comparing EPA and DHA to olive oil, paraffin oil, or placebo reported no significant reduction in CRP, IL-6, and TNF- $\alpha$ levels. Three studies [40-42] using flaxseed or flaxseed oil reported significant reduction in CRP levels. One study [31] was excluded from the meta-analysis due to lack of required data. Meta-analysis including all 12 studies $(n=662)$ reported significant difference in CRP (fixed model: $\mathrm{SMD}=-0.486 \mathrm{mg} / \mathrm{L}, 95 \% \mathrm{CI}=-0.831,-0.502, p<0.001$; random model: $\mathrm{SMD}=-0.667 \mathrm{mg} / \mathrm{L}$, $95 \% \mathrm{CI}=-0.651,-0.322 ; I^{2}=84.3 \% ; p<0.001$ ) (Figure 2). In the subgroup analysis for different forms of omega- 3 fatty acids, significant reductions in CRP were observed in studies using EPA and DHA (fixed model: $\mathrm{SMD}=-0.230 \mathrm{mg} / \mathrm{L}, 95 \% \mathrm{CI}=-0.395,-0.066, p=0.011$; random model: $\mathrm{SMD}=-0.238 \mathrm{mg} / \mathrm{L}, 95 \% \mathrm{CI}=-0.402,-0.073, p=0.009 ; I^{2}=7.0 \% ; p=0.377 ; n=9$ studies with 473 participants) or flaxseed (fixed model: $\mathrm{SMD}=-1.232 \mathrm{mg} / \mathrm{L}, 95 \% \mathrm{CI}=-1.397,-1.068, p<0.001$; random model: $\mathrm{SMD}=-2.218 \mathrm{mg} / \mathrm{L}, 95 \% \mathrm{CI}=-2.383,-2.054, p<0.001 ; I^{2}=93.4 \% ; p<0.001 ; n=3$ studies with 209 participants).

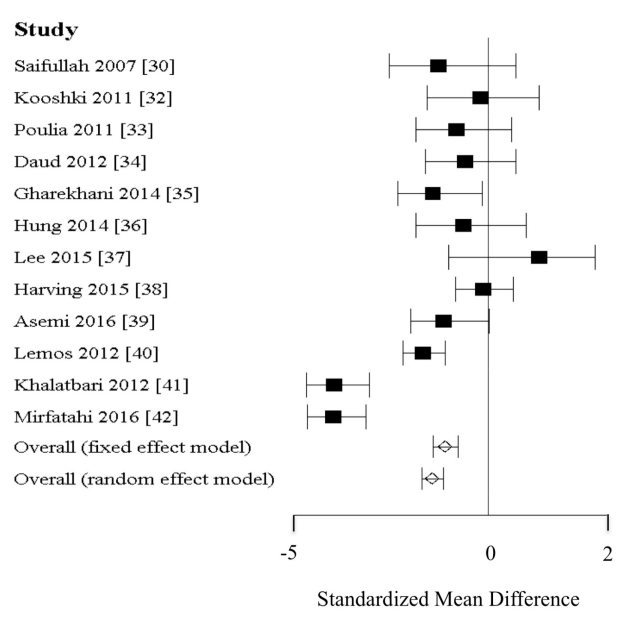

$\begin{array}{cc}\text { SMD }(\mathbf{9 5} \% \mathbf{~ C I}) & \text { \% Weight } \\ -0.58(-1.46,0.30) & 3.46 \\ -0.07(-0.75,0.60) & 5.62 \\ -0.34(-0.93,0.25) & 7.19 \\ -0.24(-0.77,0.29) & 8.76 \\ -0.66(-1.27,-0.06) & 6.82 \\ -0.26(-0.93,0.42) & 5.58 \\ 0.60(-0.44,1.64) & 2.64 \\ -0.05(-0.36,0.26) & 25.10 \\ -0.50(-1.02,0.01) & 9.27 \\ -0.82(-1.16,-0.48) & 20.70 \\ -2.98(-4.04,-1.92) & 2.29 \\ -3.00(-4.00,-2.00) & 2.56 \\ -0.486(-0.651,-0.322), p<0.001 & 30.0 \\ -0.667(-0.831,-0.502), p<0.001 & \\ I^{2}=84.3 \%, p<0.001 & \end{array}$

Figure 2. Mean changes in C-reactive protein after omega-3 fatty acids supplementation. Abbreviation: $\mathrm{CI}$, confidence interval; SMD, Standard mean difference. 


\subsection{Antioxidants}

There were 14 studies examining the efficacy of antioxidants, including vitamin $\mathrm{C}$, vitamin $\mathrm{E}$, selenium, and $\alpha$-lipoic acids on inflammatory outcomes. Of these, only the vitamin E studies were sufficient in number to permit a formal meta-analysis. Two studies [43,44] (total $n=133)$ investigated supplementation with oral vitamin $C$, but only one of these, with a bigger sample size and a higher vitamin C dosage (200 mg/day), achieved significant reduction in CRP levels [44]. Another 6 studies (total $n=350$ ) investigated the effects of vitamin E isoforms, tocopherols (TP, $n=5)[39,45-47,49]$, and tocotrienols (TT, $n=1$ ) [48] on inflammatory markers. All 6 studies reported no significant reduction in CRP levels. Two studies [49] using TP reported significant reduction in IL-6 levels post-intervention, while another study [48] using TT did not observe any significant reduction in IL-6 levels. Meta-analysis of all 6 studies $(n=310)$ reported significant difference in CRP (Fixed model: $\mathrm{SMD}=-0.257 \mathrm{mg} / \mathrm{L}, 95 \% \mathrm{CI}=-0.422,-0.093, p=0.005 ;$ Random model: $\mathrm{SMD}=-0.301 \mathrm{mg} / \mathrm{L}$, $95 \% \mathrm{CI}=-0.466,-0.137, p=0.001 ; I^{2}=48.2 \% ; p=0.086$ ) (Figure 3 ). The anti-inflammatory effect of selenium was examined in 2 studies [50,51] (total $n=124)$ with similar dose $(200 \mu \mathrm{g})$ and study duration (3 months). Both studies reported no significant reduction in CRP levels, but significant reduction in IL-6 was reported in one of the studies [50]. Five studies [47,52-55] (total $n=251$ ) examined the effects of $\alpha$-lipoic acids supplementation with similar dosage at $600 \mathrm{mg} /$ day for 2 to 3 months. Of the 5 studies, only one study [54] reported significant reduction in CRP levels, while non-significant reduction in IL-6 levels $[47,53]$ and TNF- $\alpha$ levels $[53,55]$ were reported.

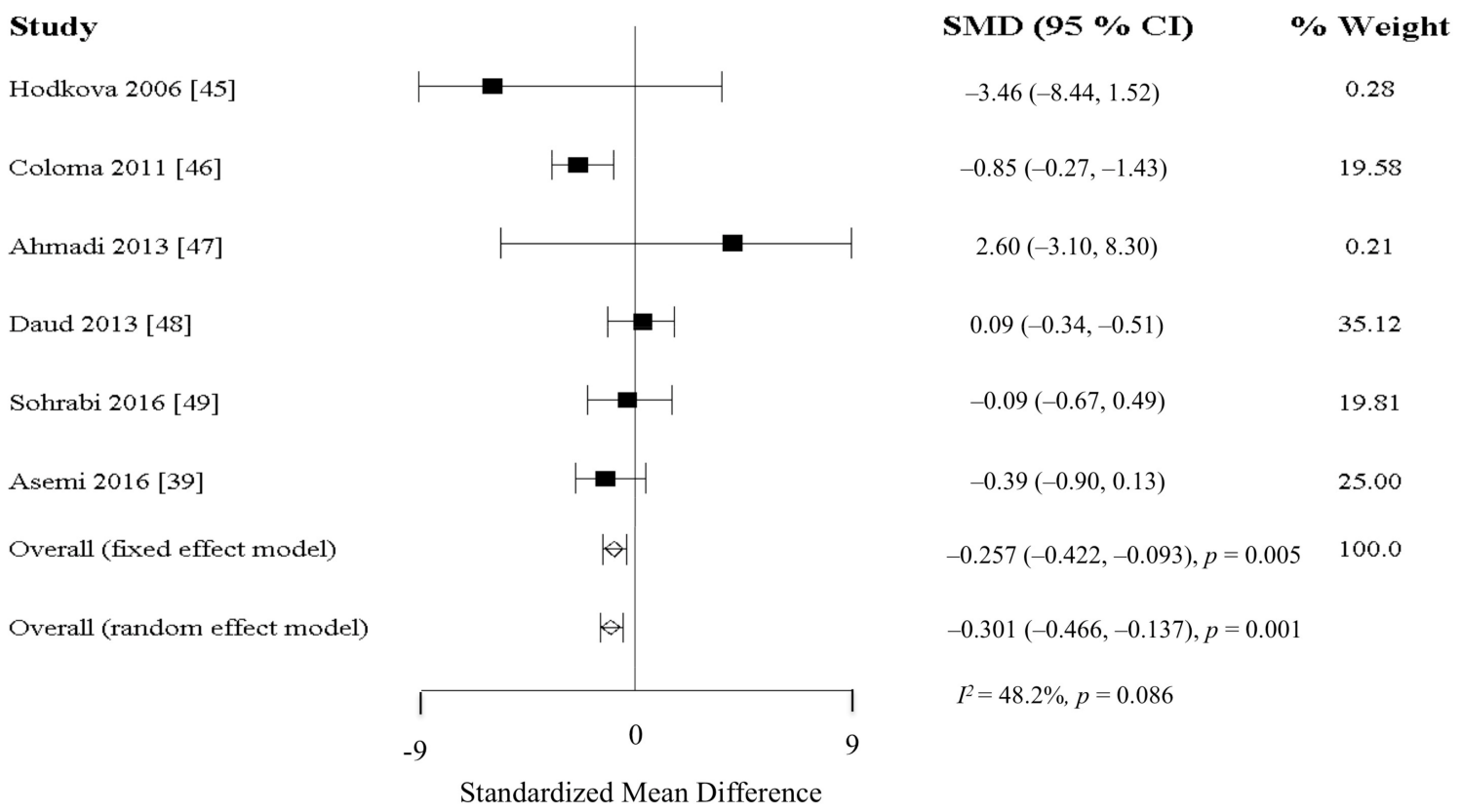

Figure 3. Mean changes in C-reactive protein after vitamin E supplementation. Abbreviation: CI, confidence interval; SMD, Standard mean difference.

\subsection{Vitamin D}

Four studies [56-59] $(n=322)$ examined the effects of different forms of oral nutritional vitamin $\mathrm{D}$ on inflammatory biomarkers, and all reported no significant reduction in either CRP, IL-6, or TNF- $\alpha$ levels. Although 4 studies were identified, the lack of required data did not permit a formal meta-analysis.

\subsection{Fibres and Probiotics}

Two studies $[60,62]$ (total $n=164$ ) investigated the effects of soluble fibre supplementation in HD patients. One study showed that consumption of $10 \mathrm{~g}$ high amylose cornstarch per day did not lead to 
significant reduction in CRP levels [60]. Contrarily, Xie et al. [62] reported significant reduction in CRP, IL-6, and TNF- $\alpha$ levels by giving either $10 \mathrm{~g} /$ day or $20 \mathrm{~g} /$ day of water-soluble fibre. One randomized parallel-arm study [63] $(n=60)$ and one randomized crossover study [61] $(n=22)$ compared probiotics of different strains to placebo in lowering CRP levels. CRP was the only inflammatory marker reported in both studies, and only 1 study demonstrated significant reduction in CRP levels [63]. The insufficient number of studies for either fibres or probiotics did not allow for a formal meta-analysis.

\subsection{Combinations}

Seven studies examined the efficacy of nutrient combinations in lowering inflammatory markers. Of these, 2 studies $[39,64]$ (total $n=123$ ) used a combination of vitamin E with omega-3 fatty acids. Both reported no significant reduction in CRP levels, while one study [64] reported significant reduction in IL-6 levels. Another 2 studies $[47,66]$ (total $n=373$ ) investigated the effects of a combination of vitamin E and $\alpha$-lipoic acids on CRP and IL-6 levels. Both studies reported no significant reduction in CRP levels. Although one study reported significant reduction in IL-6 levels [47], this effect was not observed in another study with a bigger sample size $(n=325)$ and longer study duration of 6 months [66]. One study [65] $(n=37)$ reported supplementation with an antioxidant combination of vitamin E, vitamin C, and mixed vitamin B for 2 months, but CRP and IL-6 levels did not reduce. Another study [67] $(n=42)$ compared the effects of combination therapy with symbiotic, omega-3 fatty acids, and antioxidants versus placebo for 2 months and concluded that there was no significant reduction in CRP, IL-6, and TNF- $\alpha$ levels.

\section{Discussion}

Our systematic review indicates that a large literature exists comprised of 46 RCTs of multiple types of nutritional interventions aimed at moderating inflammatory outcomes in HD patients. Figure 4 provides a schematic representation of potential mechanisms for the wide scope of nutritional interventions as anti-inflammatory agents in HD patients. The meta-analysis from the systematic review provides evidence that omega-3 fatty acids and vitamin E are able to reduce CRP levels in HD patients. For other nutritional intervention studies, the available evidence remains weak and contradictory.

Three previous systematic reviews have evaluated the effects of individual nutritional interventions on inflammatory markers in HD patients. He et al. [68], reviewing 6 studies $(n=220)$, indicated that omega-3 fatty acids in the form of EPA and DHA could reduce CRP levels but not IL-6 and TNF- $\alpha$. Another review by Xu et al. [69] included 9 studies on omega-3 fatty acids (EPA, DHA, and alpha-linolenic acid (ALA)) in a mixed population of HD, peritoneal dialysis, and non-dialysed stage 5 CKD patients. This review further supported the ability of omega- 3 fatty acids to lower CRP levels. Another meta-analysis by Marx et al. [70] with 8 studies focusing on different polyphenol groups concluded that there was a lack of significant improvement in CRP and IL-6 levels in HD patients from the pooled results. Compared to single nutritional intervention approaches, our purpose was to evaluate RCTs inclusive of a wide range of nutritional interventions. As HD patients experience inflammation triggered through multiple sources, evaluating a full spectrum of evidence allowed us to identify potential nutrition intervention beneficial to inflammatory outcomes in HD patients (Figure 4). 


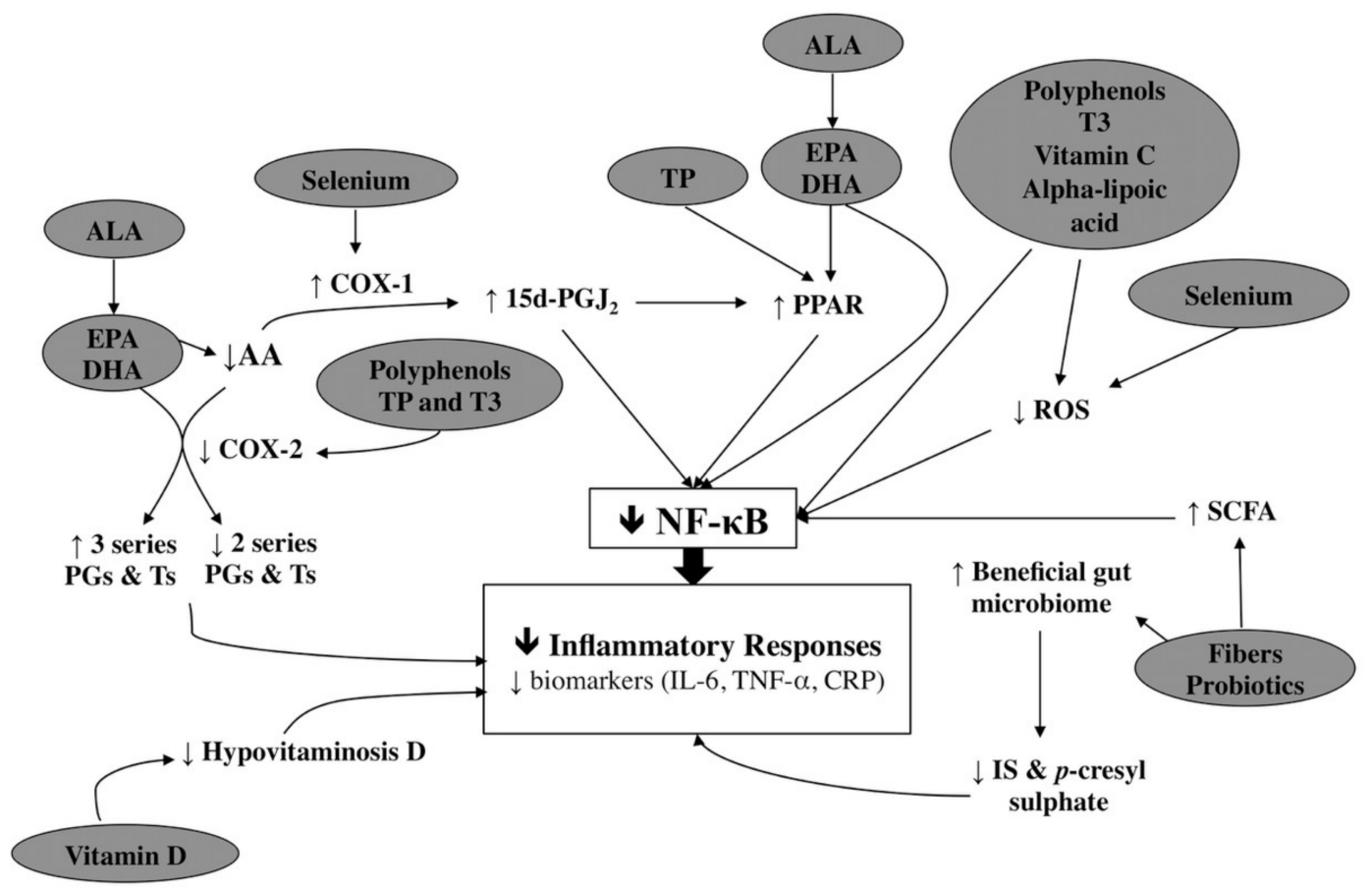

Figure 4. Proposed anti-inflammatory pathways based on reviewed nutritional interventions. Note: NF- $\mathrm{BB}$ is involved in the regulation of inflammatory response [16]. Polyphenols [71], omega-3 fatty acids, TP [72], vitamin C [73], alpha-lipoic aicids [74], and selenium [75] inhibit activation of NF- $\mathrm{kB}$ by scavenging the ROS. PPAR, a transcription factor that inhibits activation of NF- $\kappa B$, is upregulated by $\mathrm{TP}, \mathrm{EPA}$, and DHA [72,76]. TT suppresses NF- $\mathrm{B}$ gene expression directly [77]. Selenium promotes utilization of AA by COX-1 to generate $15 \mathrm{~d}-\mathrm{PGJ}_{2}$, an anti-inflammatory prostaglandin that inhibits NF- $\mathrm{BB}$ [78]. AA is metabolised by COX-2 to produce pro-inflammatory eicosanoids (PGs and Ts). EPA and DHA compete with AA for the substrate in the lipoxygenase and cyclooxygenase pathway to generate less pro-inflammatory substrates [76]. Polyphenols, TP, and TT inhibit the activity of COX-2 $[79,80]$. Fibres or probiotics stimulate the growth of saccharolytic bacteria and reduce the production of uremic toxins in the gut [18]. In addition, fermentation of soluble fibre produces SCFA, which inhibit the activities of NF- $\mathrm{B}$ [81]. Abbreviations: 15d-PGJ2, 15-deoxy- $\Delta 12,14$-prostaglandin J2; AA, arachidonic acid; ALA, alpha-linolenic acid; CRP, C-reactive protein; COX, cyclooxygenase; EPA, eicosapentaenoic acid; DHA, docosahexaenoic acid; IL-6, interleukin 6; IS, indoxyl sulphate; NF- $\mathrm{kB}$, nuclear factor kappa B; PJ, pomegranate juice; PGs, prostaglandins; PPAR, peroxisome proliferators active receptors; ROS, reactive oxygen species; SCFA, short chain fatty acids; TT, tocotrienols; Ts, thromboxanes; TNF- $\alpha$, tumor necrosis factor alpha; TP, tocopherols. Footnote: $\downarrow$, reduce; $\uparrow$, increase.

\subsection{Polyphenols}

Polyphenols are natural compounds with antioxidant and anti-inflammatory properties, commonly found in edible plant sources. Polyphenols can be distinguished into 4 groups: phenolic acids, flavonoids, stilbenes, and lignans, based on the number of phenol rings that they possess and on the structural elements that bind these rings to one another [82]. The mechanisms for mitigation of inflammatory response using polyphenols have been explored in in vivo and in vitro studies, which include (i) restoring antioxidant activities; (ii) inhibition of the pro-inflammatory enzyme; and (iii) modulation of messengers and transcription factors involved in the process of inflammation [71]. Epidemiological studies have also suggested that consumption of isoflavones may be associated with lower CRP levels in healthy populations [83] and HD patients [84]. However, our systematic review did not generate sufficient evidence to support efficacy of anti-inflammatory properties of polyphenols for HD patients, because reductions in inflammatory markers were not consistently reported in RCTs. Nevertheless, 2 RCTs with bigger sample size ( $\geq 100$ participants) 
reported positive outcomes using pomegranate juices [25] and turmeric [29]. The wide variation in polyphenols bioavailability in humans is likely to affect serum response or metabolite generation, which perhaps explains why potential health benefits are not consistently observed in these studies [82].

\subsection{Omega-3 Fatty Acids}

The meta-analysis has provided evidence to support the use of omega-3 fatty acids as anti-inflammatory therapy, either ALA or EPA and DHA. The EPA and DHA from the omega-3 polyunsaturated fatty acids (PUFA) family are well-known nutrients that confer cardiovascular benefits, potentially mediated via modulation of inflammatory response [85]. EPA and DHA have been shown to (i) regulate gene expression associated with inflammatory cytokines production such as NF- $\kappa \mathrm{B}$ and PPAR- $\gamma$; (ii) lower membrane content of arachidonic acid (AA, $n-6$ PUFA); (iii) inhibit AA metabolism; and (iv) compete with AA as substrates for the key enzymes in cyclooxygenase and lipoxygenase pathway and shift the generation of pro-inflammatory metabolites towards the production of less pro-inflammatory metabolites $[76,85]$. A fine balance in the dietary intake of $n-3$ PUFA and $n-6$ PUFA appears to be a trigger point for the type of eicosanoids generated. In HD patients with pre-existing CVD, supplementation of $1.7 \mathrm{~g} n-3$ PUFA (45\% EPA and 37.5\% DHA) per day for up to 2 years has yielded significant reduction in myocardial infarction, but not in overall CVD events and mortality [86]. In fact, a one-year prospective cohort study with $216 \mathrm{HD}$ patients observed that fish consumption was associated with improved survival [87]. The ALA also belongs to the omega-3 PUFA family and is an essential nutrient in human diet [88]. Although ALA is a metabolic precursor of EPA and DHA, in vivo conversion of ALA to EPA and DHA in humans is relatively inefficient and large amounts of ALA is required [85]. Therefore, the anti-inflammatory effects of ALA may also be attributed to inhibition of NF- $\mathrm{kB}$ and down regulation of the inflammatory gene expression [89]. A meta-analysis by Su et al. [90] concluded that dietary ALA had no effects on blood inflammatory markers in a mixed population. However, the author suggested that anti-inflammatory effects of ALA might only be evident in populations with elevated inflammatory markers.

\subsection{Antioxidants}

Oxidative stress is closely linked to inflammation; therefore the anti-inflammatory effects of nutrients with antioxidant properties, namely vitamin C, vitamin E, selenium, and alpha-lipoic acids, were identified as typical anti-inflammatory agents for treating HD patients.

Vitamin C, a water-soluble vitamin with antioxidant properties, is commonly depleted in HD patients due to dietary restriction of vitamin C-rich food such as fruits and vegetables and losses during haemodialysis. In a cross-sectional study $(n=117)$, plasma vitamin C levels in HD patients were inversely correlated with hsCRP levels [91]. However, research on the use of vitamin C in HD patients has mainly focused on anaemia management [92], and the efficacy of vitamin $C$ in modulating inflammatory response in HD patients remains largely unexplored.

On the other hand, more studies on vitamin E were available, predominantly in the form of tocopherols (TP) instead of tocotrienols (TT). Although TP and TT share a close structural similarity, TP and TT have distinct biological activities [93]. The anti-inflammatory effect of both TP and TT in reducing serum CRP levels has been documented in a heterogeneous population [94,95]. A meta-analysis also indicated a reduction in oxidative stress and inflammation outcomes with a dialyzer coated with vitamin E compared to a conventional dialyzer [96]. The Secondary Prevention with Antioxidants of Cardiovascular Disease in End Stage Renal Disease reported that the supplementation of $800 \mathrm{IU} /$ day $\alpha$-TP achieved reductions in composite CVD endpoints and myocardial infarction without affecting total mortality in HD patients with pre-existing CVD [97]. Although our finding is consistent with previous literature that found favourable effects with vitamin E supplementation, The Provision of Antioxidant Therapy in Haemodialysis study was not included in our meta-analysis due to the use of a combination of nutrients [66]. This study examined the efficacy of a combination of mixed TP (666 IU/day) and $\alpha$-lipoic acid (600 mg/day) in $355 \mathrm{HD}$ patients for a 
6-month duration and reported no significant improvement in any of the inflammatory markers after 6 months of antioxidant therapy.

Selenium (Se) is an essential trace element, which acts as an integral structural component of gluthathione peroxidase (GSH-Px), a well-established enzymatic player against oxidative stress through reducing ROS [75]. HD patients generally have lower blood Se concentrations compared to the general population [98], and serum Se concentrations in HD patients were found to be negatively associated with hsCRP levels [99]. Supplementation with Se-enriched yeast increases plasma Se concentrations in HD patients, but plasma GSH-Px concentrations were not impacted. The kidney is suggested as the main site for plasma GSH-Px synthesis, and low plasma GSH-Px levels in CKD patients therefore may not be related to Se deficiency but may rather be due to the failure of the kidneys to synthesize GSH-Px $[100,101]$. Therefore, the potential beneficial effect of Se supplementation to lower inflammation in HD patients remains unknown.

Alpha-lipoic acid is another naturally occurring antioxidant, which has been suggested to mitigate oxidative stress associated inflammation by scavenging free radicals and inhibiting the pro-inflammatory pathway [74]. Therapeutic applications of alpha-lipoic acid have been commonly reported in many chronic diseases such as obesity, diabetes, and cognitive dysfunctions [102]. However, limited evidence is available to recommend routine supplementation of alpha-lipoic acid in HD patients.

\subsection{Vitamin D}

Vitamin D deficiency is prevalent and has been associated with inflammation in HD patients [103]. Although a 1-year prospective study reported oral vitamin D supplementation attenuated inflammation by reducing CRP levels in HD patients [104], evidence from existing RCTs does not support the role of nutritional vitamin $\mathrm{D}$ in modulating inflammation in HD patients.

\subsection{Fibers and Probiotics}

Prospective cohort studies and experimental human feeding interventions in the general population, as well as in CKD patients, have demonstrated that high dietary fibre is associated with lower inflammatory markers [105-107]. A recent meta-analysis of intervention studies on a mixed population reported favourable effects of prebiotic and symbiotic supplementations on systemic inflammation [108]. The benefits of dietary fibre on inflammatory outcomes can be attributed to modulation of bowel flora environment and the pleotropic presence of co-nutrients in high fibre foods such as fruits, vegetables, and wholegrain products. HD patients are known to have lower fibre intake, which is reflective of a suboptimal intake of whole grains, fruits, and vegetables for the purpose of potassium restriction [109]. However, there is insufficient evidence demonstrating that either routine consumption of fibres or probiotics can improve gut microbiome in HD patients and subsequently improve inflammatory outcomes in HD patients.

\subsection{Limitations}

Our review has some limitations. Firstly, we included only papers published in the English language. Second, we included studies providing nutritional intervention through the oral route only, and therefore these findings cannot be extrapolated to the intravenous route of nutrient delivery. Third, the heterogeneity of these studies with diverse nutritional interventions did not allow for formal meta-analyses, with the exception of omega-3 fatty acids and vitamin E studies. In addition, adequacy of haemodialysis and dietary intake or adequacy were not controlled or analysed and could have influenced patients' response. Methods of inflammatory marker analyses were not known or controlled. On this subject we must add that these inflammatory markers are involved in both acute and chronic inflammatory processes. Therefore, events such as infection and acute illness are likely to contribute to significant within-individual variation [110]. 


\section{Conclusions}

In conclusion, our systematic review and meta-analysis of the existing literature suggest that omega-3 fatty acids and vitamin E alone are effective in lowering CRP levels in supplemented HD patients. However, available evidence for other anti-inflammatory nutritional therapies remains inconclusive and uncertain due to the small number of studies and sample size of the intervention populations. Future studies designed with optimal sample size to provide adequate statistical power and of longer study duration are required and should be extended beyond inflammation to clinical outcomes such as cardiovascular mortality.

Supplementary Materials: The following are available online at www.mdpi.com/2072-6643/10/4/397/s1, Table S1: Study Selection Based on Inclusion Criteria after Reviewing Full Text.

Acknowledgments: B.-H.K. is a candidate receiving the Chancellor's Research Scholarship (Zamalah Yayasan Canselor) from Universiti Kebangsaan Malaysia.

Author Contributions: B.-H.K., S.S.N. and T.K. were involved in all processes of the review from literature search, study selection, data extraction, and quality assessment, K.C. conducted the meta-analysis, S.S.N., S.S., A.H.A.G., Z.A.M.D., P.K., A.S. and E.F. contributed to the writing and critical revision of the manuscript. All authors read, critically revised, and approved the final manuscript.

Conflicts of Interest: The authors declare no conflict of interest.

\section{References}

1. United States Renal Data System. 2017 USRDS Annual Data Report: Epidemiology of Kidney Disease in the United States; National Institutes of Health: Bethesda, MD, USA; National Institute of Diabetes and Digestive and Kidney Diseases: Bethesda, MD, USA, 2017.

2. Kilpatrick, R.D.; McAllister, C.J.; Kovesdy, C.P.; Derose, S.F.; Kopple, J.D.; Kalantar-Zadeh, K. Association between serum lipids and survival in hemodialysis patients and impact of race. J. Am. Soc. Nephrol. 2007, 18, 293-303. [CrossRef] [PubMed]

3. Kopple, J.D. The phenomenon of altered risk factor patterns or reverse epidemiology in persons with advanced chronic kidney failure. Am. J. Clin. Nutr. 2005, 81, 1257-1266. [CrossRef] [PubMed]

4. Stenvinkel, P.; Alvestrand, A. Inflammation in end-stage renal disease: Sources, consequences, and therapy. Semin. Dial. 2002, 15, 329-337. [CrossRef] [PubMed]

5. Medzhitov, R. Origin and physiological roles of inflammation. Nature 2008, 454, 428-435. [CrossRef] [PubMed]

6. Bazeley, J.; Bieber, B.; Li, Y.; Morgenstern, H.; de Sequera, P.; Combe, C.; Yamamoto, H.; Gallagher, M.; Port, F.K.; Robinson, B.M. C-reactive protein and prediction of 1-year mortality in prevalent hemodialysis patients. Clin. J. Am. Soc. Nephrol. 2011, 6, 2452-2461. [CrossRef] [PubMed]

7. Panichi, V.; Maggiore, U.; Taccola, D.; Migliori, M.; Rizza, G.M.; Consani, C.; Bertini, A.; Sposini, S.; Perez-Garcia, R.; Rindi, P.; et al. Interleukin-6 is a stronger predictor of total and cardiovascular mortality than C-reactive protein in haemodialysis patients. Nephrol. Dial. Transplant. 2004, 19, 1154-1160. [CrossRef] [PubMed]

8. Sabatino, A.; Regolisti, G.; Karupaiah, T.; Sahathevan, S.; Sadu Singh, B.K.; Khor, B.H.; Salhab, N.; Karavetian, M.; Cupisti, A.; Fiaccadori, E. Protein-energy wasting and nutritional supplementation in patients with end-stage renal disease on hemodialysis. Clin. Nutr. 2017, 36, 663-671. [CrossRef] [PubMed]

9. Carrero, J.J.; Stenvinkel, P. Inflammation in end-stage renal disease-What have we learned in 10 years? Semin. Dial. 2010, 23, 498-509. [CrossRef] [PubMed]

10. Oberg, B.P.; McMenamin, E.; Lucas, F.L.; McMonagle, E.; Morrow, J.; Ikizler, T.A.; Himmelfarb, J. Increased prevalence of oxidant stress and inflammation in patients with moderate to severe chronic kidney disease. Kidney Int. 2004, 65, 1009-1016. [CrossRef] [PubMed]

11. Caglar, K.; Peng, Y.; Pupim, L.B.; Flakoll, P.J.; Levenhagen, D.; Hakim, R.M.; Ikizler, T.A. Inflammatory signals associated with hemodialysis. Kidney Int. 2002, 62, 1408-1416. [CrossRef] [PubMed]

12. Sachdeva, M.; Hung, A.; Kovalchuk, O.; Bitzer, M.; Mokrzycki, M.H. The initial vascular access type contributes to inflammation in incident hemodialysis patients. Int. J. Nephrol. 2012, 2012, 917465. [CrossRef] [PubMed] 
13. Susantitaphong, P.; Riella, C.; Jaber, B.L. Effect of ultrapure dialysate on markers of inflammation, oxidative stress, nutrition and anemia parameters: A meta-analysis. Nephrol. Dial. Transplant. 2013, 28, 438-446. [CrossRef] [PubMed]

14. Libetta, C.; Sepe, V.; Esposito, P.; Galli, F.; Dal Canton, A. Oxidative stress and inflammation: Implications in uremia and hemodialysis. Clin. Biochem. 2011, 44, 1189-1198. [CrossRef] [PubMed]

15. Biswas, S.K. Does the interdependence between oxidative stress and inflammation explain the antioxidant paradox? Oxid. Med. Cell. Longev. 2016, 2016, 5698931. [CrossRef] [PubMed]

16. Sanz, A.B.; Sanchez-Nino, M.D.; Ramos, A.M.; Moreno, J.A.; Santamaria, B.; Ruiz-Ortega, M.; Egido, J.; Ortiz, A. Nf-kappab in renal inflammation. J. Am. Soc. Nephrol. 2010, 21, 1254-1262. [CrossRef] [PubMed]

17. Lau, W.L.; Kalantar-Zadeh, K.; Vaziri, N.D. The gut as a source of inflammation in chronic kidney disease. Nephron 2015, 130, 92-98. [CrossRef] [PubMed]

18. Sabatino, A.; Regolisti, G.; Brusasco, I.; Cabassi, A.; Morabito, S.; Fiaccadori, E. Alterations of intestinal barrier and microbiota in chronic kidney disease. Nephrol. Dial. Transplant. 2015, 30, 924-933. [CrossRef] [PubMed]

19. Machowska, A.; Carrero, J.J.; Lindholm, B.; Stenvinkel, P. Therapeutics targeting persistent inflammation in chronic kidney disease. Transl. Res. 2016, 167, 204-213. [CrossRef] [PubMed]

20. Stenvinkel, P. Inflammation in end-stage renal disease: The hidden enemy. Nephrology 2006, 11, 36-41. [CrossRef] [PubMed]

21. Jadad, A.R.; Moore, R.A.; Carroll, D.; Jenkinson, C.; Reynolds, D.J.; Gavaghan, D.J.; McQuay, H.J. Assessing the quality of reports of randomized clinical trials: Is blinding necessary? Control Clin. Trials 1996, 17, 1-12. [CrossRef]

22. Fanti, P.; Asmis, R.; Stephenson, T.J.; Sawaya, B.P.; Franke, A.A. Positive effect of dietary soy in ESRD patients with systemic inflammation-Correlation between blood levels of the soy isoflavones and the acute-phase reactants. Nephrol. Dial. Transplant. 2006, 21, 2239-2246. [CrossRef] [PubMed]

23. Siefker, K.; DiSilvestro, R.A. Safety and antioxidant effects of a modest soy protein intervention in hemodialysis patients. J. Med. Food 2006, 9, 368-372. [CrossRef] [PubMed]

24. Tomayko, E.J.; Kistler, B.M.; Fitschen, P.J.; Wilund, K.R. Intradialytic protein supplementation reduces inflammation and improves physical function in maintenance hemodialysis patients. J. Ren. Nutr. 2015, 25, 276-283. [CrossRef] [PubMed]

25. Shema-Didi, L.; Sela, S.; Ore, L.; Shapiro, G.; Geron, R.; Moshe, G.; Kristal, B. One year of pomegranate juice intake decreases oxidative stress, inflammation, and incidence of infections in hemodialysis patients: A randomized placebo-controlled trial. Free Radic. Biol. Med. 2012, 53, 297-304. [CrossRef] [PubMed]

26. Wu, P.T.; Fitschen, P.J.; Kistler, B.M.; Jeong, J.H.; Chung, H.R.; Aviram, M.; Phillips, S.A.; Fernhall, B.; Wilund, K.R. Effects of pomegranate extract supplementation on cardiovascular risk factors and physical function in hemodialysis patients. J. Med. Food 2015, 18, 941-949. [CrossRef] [PubMed]

27. Rassaf, T.; Rammos, C.; Hendgen-Cotta, U.B.; Heiss, C.; Kleophas, W.; Dellanna, F.; Floege, J.; Hetzel, G.R.; Kelm, M. Vasculoprotective effects of dietary cocoa flavanols in patients on hemodialysis: A double-blind, randomized, placebo-controlled trial. Clin. J. Am. Soc. Nephrol. 2016, 11, 108-118. [CrossRef] [PubMed]

28. Janiques, A.G.; de Oliveira Leal, O.; Stockler-Pinto, M.B.; Moreira, N.X.; Mafra, D. Effects of grape powder supplementation on inflammatory and antioxidant markers in hemodialysis patients: A randomized double-blind study. J. Bras. Nefrol. 2014, 36, 496-501. [CrossRef] [PubMed]

29. Pakfetrat, M.; Basiri, F.; Malekmakan, L.; Roozbeh, J. Effects of turmeric on uremic pruritus in end stage renal disease patients: A double-blind randomized clinical trial. J. Nephrol. 2014, 27, 203-207. [CrossRef] [PubMed]

30. Saifullah, A.; Watkins, B.A.; Saha, C.; Li, Y.; Moe, S.M.; Friedman, A.N. Oral fish oil supplementation raises blood omega-3 levels and lowers C-reactive protein in haemodialysis patients-A pilot study. Nephrol. Dial. Transplant. 2007, 22, 3561-3567. [CrossRef] [PubMed]

31. Bowden, R.G.; Wilson, R.L.; Deike, E.; Gentile, M. Fish oil supplementation lowers C-reactive protein levels independent of triglyceride reduction in patients with end-stage renal disease. Nutr. Clin. Pract. 2009, 24, 508-512. [CrossRef] [PubMed]

32. Kooshki, A.; Taleban, F.A.; Tabibi, H.; Hedayati, M. Effects of omega-3 fatty acids on serum lipids, lipoprotein (a), and hematologic factors in hemodialysis patients. Ren. Fail. 2011, 33, 892-898. [CrossRef] [PubMed] 
33. Poulia, K.A.; Panagiotakos, D.B.; Tourlede, E.; Rezou, A.; Stamatiadis, D.; Boletis, J.; Zampelas, A. Omega-3 fatty acids supplementation does not affect serum lipids in chronic hemodialysis patients. J. Ren. Nutr. 2011, 21, 479-484. [CrossRef] [PubMed]

34. Daud, Z.A.; Tubie, B.; Adams, J.; Quainton, T.; Osia, R.; Tubie, S.; Kaur, D.; Khosla, P.; Sheyman, M. Effects of protein and omega-3 supplementation, provided during regular dialysis sessions, on nutritional and inflammatory indices in hemodialysis patients. Vasc. Health Risk Manag. 2012, 8, 187-195. [PubMed]

35. Gharekhani, A.; Khatami, M.R.; Dashti-Khavidaki, S.; Razeghi, E.; Noorbala, A.A.; Hashemi-Nazari, S.S.; Mansournia, M.A. The effect of omega-3 fatty acids on depressive symptoms and inflammatory markers in maintenance hemodialysis patients: A randomized, placebo-controlled clinical trial. Eur. J. Clin. Pharmacol. 2014, 70, 655-665. [CrossRef] [PubMed]

36. Hung, A.M.; Booker, C.; Ellis, C.D.; Siew, E.D.; Graves, A.J.; Shintani, A.; Abumrad, N.N.; Himmelfarb, J.; Ikizler, T.A. Omega-3 fatty acids inhibit the up-regulation of endothelial chemokines in maintenance hemodialysis patients. Nephrol. Dial. Transplant. 2015, 30, 266-274. [CrossRef] [PubMed]

37. Lee, S.M.; Son, Y.K.; Kim, S.E.; An, W.S. The effects of omega-3 fatty acid on vitamin D activation in hemodialysis patients: A pilot study. Mar. Drugs 2015, 13, 741-755. [CrossRef] [PubMed]

38. Harving, F.; Svensson, M.; Flyvbjerg, A.; Schmidt, E.B.; Jorgensen, K.A.; Eriksen, H.H.; Christensen, J.H. N-3 polyunsaturated fatty acids and adiponectin in patients with end-stage renal disease. Clin. Nephrol. 2015, 83, 279-285. [CrossRef] [PubMed]

39. Asemi, Z.; Soleimani, A.; Shakeri, H.; Mazroii, N.; Esmaillzadeh, A. Effects of omega-3 fatty acid plus alpha-tocopherol supplementation on malnutrition-inflammation score, biomarkers of inflammation and oxidative stress in chronic hemodialysis patients. Int. J. Nephrol. Urol. 2016, 48, 1887-1895. [CrossRef] [PubMed]

40. Lemos, J.R.; Alencastro, M.G.; Konrath, A.V.; Cargnin, M.; Manfro, R.C. Flaxseed oil supplementation decreases C-reactive protein levels in chronic hemodialysis patients. Nutr. Res. 2012, 32, 921-927. [CrossRef] [PubMed]

41. Khalatbari Soltani, S.; Jamaluddin, R.; Tabibi, H.; Mohd Yusof, B.N.; Atabak, S.; Loh, S.P.; Rahmani, L. Effects of flaxseed consumption on systemic inflammation and serum lipid profile in hemodialysis patients with lipid abnormalities. Hemodial. Int. 2013, 17, 275-281. [CrossRef] [PubMed]

42. Mirfatahi, M.; Tabibi, H.; Nasrollahi, A.; Hedayati, M.; Taghizadeh, M. Effect of flaxseed oil on serum systemic and vascular inflammation markers and oxidative stress in hemodialysis patients: A randomized controlled trial. Int. J. Nephrol. Urol. 2016, 48, 1335-1341. [CrossRef] [PubMed]

43. Fumeron, C.; Nguyen-Khoa, T.; Saltiel, C.; Kebede, M.; Buisson, C.; Drueke, T.B.; Lacour, B.; Massy, Z.A. Effects of oral vitamin $C$ supplementation on oxidative stress and inflammation status in haemodialysis patients. Nephrol. Dial. Transplant. 2005, 20, 1874-1879. [CrossRef] [PubMed]

44. Zhang, K.; Li, Y.; Cheng, X.; Liu, L.; Bai, W.; Guo, W.; Wu, L.; Zuo, L. Cross-over study of influence of oral vitamin $C$ supplementation on inflammatory status in maintenance hemodialysis patients. BMC Nephrol. 2013, 14, 252. [CrossRef] [PubMed]

45. Hodkova, M.; Dusilova-Sulkova, S.; Kalousova, M.; Soukupova, J.; Zima, T.; Mikova, D.; Malbohan, I.M.; Bartunkova, J. Influence of oral vitamin E therapy on micro-inflammation and cardiovascular disease markers in chronic hemodialysis patients. Ren. Fail. 2006, 28, 395-399. [CrossRef] [PubMed]

46. Coloma, R.S.; Jocson, V.R.A. Effects of vitamin E on a biomarker of inflammation and precursors of atherogenesis in chronic hemodialysis patients. Philipp. J. Intern. Med. 2011, 49, 206-215.

47. Ahmadi, A.; Mazooji, N.; Roozbeh, J.; Mazloom, Z.; Hasanzade, J. Effect of alpha-lipoic acid and vitamin E supplementation on oxidative stress, inflammation, and malnutrition in hemodialysis patients. Iran. J. Kidney Dis. 2013, 7, 461-467. [PubMed]

48. Daud, Z.A.; Tubie, B.; Sheyman, M.; Osia, R.; Adams, J.; Tubie, S.; Khosla, P. Vitamin E tocotrienol supplementation improves lipid profiles in chronic hemodialysis patients. Vasc. Health Risk Manag. 2013, 9, 747-761. [PubMed]

49. Sohrabi, Z.; Eftekhari, M.H.; Eskandari, M.H.; Rezaianzadeh, A.; Sagheb, M.M. Intradialytic oral protein supplementation and nutritional and inflammation outcomes in hemodialysis: A randomized controlled trial. Am. J. Kidney Dis. 2016, 68, 122-130. [CrossRef] [PubMed] 
50. Salehi, M.; Sohrabi, Z.; Ekramzadeh, M.; Fallahzadeh, M.K.; Ayatollahi, M.; Geramizadeh, B.; Hassanzadeh, J.; Sagheb, M.M. Selenium supplementation improves the nutritional status of hemodialysis patients: A randomized, double-blind, placebo-controlled trial. Nephrol. Dial. Transplant. 2013, 28, 716-723. [CrossRef] [PubMed]

51. Omrani, H.R.; Rahimi, M.; Nikseresht, K. The effect of selenium supplementation on acute phase reactants and thyroid function tests in hemodialysis patients. Nephrourol. Mon. 2015, 7, e24781. [CrossRef] [PubMed]

52. Chang, J.W.; Lee, E.K.; Kim, T.H.; Min, W.K.; Chun, S.; Lee, K.U.; Kim, S.B.; Park, J.S. Effects of alpha-lipoic acid on the plasma levels of asymmetric dimethylarginine in diabetic end-stage renal disease patients on hemodialysis: A pilot study. Am. J. Nephrol. 2007, 27, 70-74. [CrossRef] [PubMed]

53. El-Nakib, G.A.; Mostafa, T.M.; Abbas, T.M.; El-Shishtawy, M.M.; Mabrouk, M.M.; Sobh, M.A. Role of alpha-lipoic acid in the management of anemia in patients with chronic renal failure undergoing hemodialysis. Int. J. Nephrol. Renovasc. Dis. 2013, 6, 161-168. [CrossRef] [PubMed]

54. Khabbazi, T.; Mahdavi, R.; Safa, J.; Pour-Abdollahi, P. Effects of alpha-lipoic acid supplementation on inflammation, oxidative stress, and serum lipid profile levels in patients with end-stage renal disease on hemodialysis. J. Ren. Nutr. 2012, 22, 244-250. [CrossRef] [PubMed]

55. Safa, J.; Ardalan, M.R.; Rezazadehsaatlou, M.; Mesgari, M.; Mahdavi, R.; Jadid, M.P. Effects of alpha lipoic acid supplementation on serum levels of IL-8 and TNF-alpha in patient with ESRD undergoing hemodialysis. Int. J. Nephrol. Urol. 2014, 46, 1633-1638. [CrossRef] [PubMed]

56. Marckmann, P.; Agerskov, H.; Thineshkumar, S.; Bladbjerg, E.M.; Sidelmann, J.J.; Jespersen, J.; Nybo, M.; Rasmussen, L.M.; Hansen, D.; Scholze, A. Randomized controlled trial of cholecalciferol supplementation in chronic kidney disease patients with hypovitaminosis D. Nephrol. Dial. Transplant. 2012, 27, 3523-3531. [CrossRef] [PubMed]

57. Hung, A.M.; Sundell, M.B.; Plotnikova, N.E.; Bian, A.; Shintani, A.; Ellis, C.D.; Siew, E.D.; Ikizler, T.A. A pilot study of active vitamin D administration and insulin resistance in African American patients undergoing chronic hemodialysis. J. Ren. Nutr. 2013, 23, 185-193. [CrossRef] [PubMed]

58. Seibert, E.; Heine, G.H.; Ulrich, C.; Seiler, S.; Kohler, H.; Girndt, M. Influence of cholecalciferol supplementation in hemodialysis patients on monocyte subsets: A randomized, double-blind, placebo-controlled clinical trial. Nephron Clin. Pract. 2013, 123, 209-219. [CrossRef] [PubMed]

59. Miskulin, D.C.; Majchrzak, K.; Tighiouart, H.; Muther, R.S.; Kapoian, T.; Johnson, D.S.; Weiner, D.E. Ergocalciferol supplementation in hemodialysis patients with vitamin d deficiency: A randomized clinical trial. J. Am. Soc. Nephrol. 2016, 27, 1801-1810. [CrossRef] [PubMed]

60. Sirich, T.L.; Plummer, N.S.; Gardner, C.D.; Hostetter, T.H.; Meyer, T.W. Effect of increasing dietary fiber on plasma levels of colon-derived solutes in hemodialysis patients. Clin. J. Am. Soc. Nephrol. 2014, 9, 1603-1610. [CrossRef] [PubMed]

61. Natarajan, R.; Pechenyak, B.; Vyas, U.; Ranganathan, P.; Weinberg, A.; Liang, P.; Mallappallil, M.C.; Norin, A.J.; Friedman, E.A.; Saggi, S.J. Randomized controlled trial of strain-specific probiotic formulation (Renadyl) in dialysis patients. Biomed Res. Int. 2014, 2014, 568571. [CrossRef] [PubMed]

62. Xie, L.M.; Ge, Y.Y.; Huang, X.; Zhang, Y.Q.; Li, J.X. Effects of fermentable dietary fiber supplementation on oxidative and inflammatory status in hemodialysis patients. Int. J. Clin. Exp. Med. 2015, 8, 1363-1369. [PubMed]

63. Soleimani, A.; Zarrati Mojarrad, M.; Bahmani, F.; Taghizadeh, M.; Ramezani, M.; Tajabadi-Ebrahimi, M.; Jafari, P.; Esmaillzadeh, A.; Asemi, Z. Probiotic supplementation in diabetic hemodialysis patients has beneficial metabolic effects. Kidney Int. 2017, 91, 435-442. [CrossRef] [PubMed]

64. Himmelfarb, J.; Phinney, S.; Ikizler, T.A.; Kane, J.; McMonagle, E.; Miller, G. Gamma-tocopherol and docosahexaenoic acid decrease inflammation in dialysis patients. J. Ren. Nutr. 2007, 17, 296-304. [CrossRef] [PubMed]

65. Kamgar, M.; Zaldivar, F.; Vaziri, N.D.; Pahl, M.V. Antioxidant therapy does not ameliorate oxidative stress and inflammation in patients with end-stage renal disease. J. Natl. Med. Assoc. 2009, 101, 336-344. [CrossRef]

66. Himmelfarb, J.; Ikizler, T.A.; Ellis, C.; Wu, P.; Shintani, A.; Dalal, S.; Kaplan, M.; Chonchol, M.; Hakim, R.M. Provision of antioxidant therapy in hemodialysis (PATH): A randomized clinical trial. J. Am. Soc. Nephrol. 2014, 25, 623-633. [CrossRef] [PubMed] 
67. Viramontes-Horner, D.; Marquez-Sandoval, F.; Martin-del-Campo, F.; Vizmanos-Lamotte, B.; Sandoval-Rodriguez, A.; Armendariz-Borunda, J.; Garcia-Bejarano, H.; Renoirte-Lopez, K.; Garcia-Garcia, G. Effect of a symbiotic gel (lactobacillus acidophilus + bifidobacterium lactis + inulin) on presence and severity of gastrointestinal symptoms in hemodialysis patients. J. Ren. Nutr. 2015, 25, 284-291. [CrossRef] [PubMed]

68. He, L.; Li, M.S.; Lin, M.; Zhao, T.Y.; Gao, P. Effect of fish oil supplement in maintenance hemodialysis patients: A systematic review and meta-analysis of published randomized controlled trials. Eur. J. Clin. Pharmacol. 2016, 72, 129-139. [CrossRef] [PubMed]

69. Xu, T.; Sun, Y.; Sun, W.; Yao, L.; Sun, L.; Liu, L.; Ma, J.; Wang, L. Effect of omega-3 fatty acid supplementation on serum lipids and vascular inflammation in patients with end-stage renal disease: A meta-analysis. Sci. Rep. 2016, 6, 39346. [CrossRef] [PubMed]

70. Marx, W.; Kelly, J.; Marshall, S.; Nakos, S.; Campbell, K.; Itsiopoulos, C. The effect of polyphenol-rich interventions on cardiovascular risk factors in haemodialysis: A systematic review and meta-analysis. Nutrients 2017, 9, 12. [CrossRef] [PubMed]

71. Hussain, T.; Tan, B.; Yin, Y.; Blachier, F.; Tossou, M.C.; Rahu, N. Oxidative stress and inflammation: What polyphenols can do for us? Oxid. Med. Cell. Longev. 2016, 2016, 7432797. [CrossRef] [PubMed]

72. Reiter, E.; Jiang, Q.; Christen, S. Anti-inflammatory properties of alpha- and gamma-tocopherol. Mol. Asp. Med. 2007, 28, 668-691. [CrossRef] [PubMed]

73. Bowie, A.G.; O'Neill, L.A. Vitamin C inhibits NF-kappa B activation by TNF via the activation of p38 mitogen-activated protein kinase. J. Immunol. 2000, 165, 7180-7188. [CrossRef] [PubMed]

74. Shay, K.P.; Moreau, R.F.; Smith, E.J.; Smith, A.R.; Hagen, T.M. Alpha-lipoic acid as a dietary supplement: Molecular mechanisms and therapeutic potential. Biochim. Biophys. Acta 2009, 1790, 1149-1160. [CrossRef] [PubMed]

75. Duntas, L.H. Selenium and inflammation: Underlying anti-inflammatory mechanisms. Horm. Metab. Res. 2009, 41, 443-447. [CrossRef] [PubMed]

76. Calder, P.C. Mechanisms of action of (n-3) fatty acids. J. Nutr. 2012, 142, 592s-599s. [CrossRef] [PubMed]

77. Kaileh, M.; Sen, R. Role of nf-kappab in the anti-inflammatory effects of tocotrienols. J. Am. Coll. Nutr. 2010, 29, 334s-339s. [CrossRef] [PubMed]

78. Vunta, H.; Davis, F.; Palempalli, U.D.; Bhat, D.; Arner, R.J.; Thompson, J.T.; Peterson, D.G.; Reddy, C.C.; Prabhu, K.S. The anti-inflammatory effects of selenium are mediated through 15-deoxy-delta12,14prostaglandin $\mathrm{J}_{2}$ in macrophages. J. Biol. Chem. 2007, 282, 17964-17973. [CrossRef] [PubMed]

79. Khan, A.Q.; Khan, R.; Rehman, M.U.; Lateef, A.; Tahir, M.; Ali, F.; Sultana, S. Soy isoflavones (daidzein \& genistein) inhibit 12-O-tetradecanoylphorbol-13-acetate (TPA)-induced cutaneous inflammation via modulation of COX-2 and NF-kappaB in swiss albino mice. Toxicology 2012, 302, 266-274. [PubMed]

80. Yam, M.L.; Abdul Hafid, S.R.; Cheng, H.M.; Nesaretnam, K. Tocotrienols suppress proinflammatory markers and cyclooxygenase-2 expression in raw264.7 macrophages. Lipids 2009, 44, 787-797. [CrossRef] [PubMed]

81. Meijer, K.; de Vos, P.; Priebe, M.G. Butyrate and other short-chain fatty acids as modulators of immunity: What relevance for health? Curr. Opin. Clin. Nutr. Metab. Care 2010, 13, 715-721. [CrossRef] [PubMed]

82. Manach, C.; Scalbert, A.; Morand, C.; Remesy, C.; Jimenez, L. Polyphenols: Food sources and bioavailability. Am. J. Clin. Nutr. 2004, 79, 727-747. [CrossRef] [PubMed]

83. Chun, O.K.; Chung, S.J.; Claycombe, K.J.; Song, W.O. Serum C-reactive protein concentrations are inversely associated with dietary flavonoid intake in U.S. Adults. J. Nutr. 2008, 138, 753-760. [CrossRef] [PubMed]

84. Fanti, P.; Stephenson, T.J.; Kaariainen, I.M.; Rezkalla, B.; Tsukamoto, Y.; Morishita, T.; Nomura, M.; Kitiyakara, C.; Custer, L.J.; Franke, A.A. Serum isoflavones and soya food intake in japanese, thai and american end-stage renal disease patients on chronic haemodialysis. Nephrol. Dial. Transplant. 2003, 18, 1862-1868. [CrossRef] [PubMed]

85. Mori, T.A.; Beilin, L.J. Omega-3 fatty acids and inflammation. Curr. Atheroscler. Rep. 2004, 6, 461-467. [CrossRef] [PubMed]

86. Svensson, M.; Schmidt, E.B.; Jorgensen, K.A.; Christensen, J.H. N-3 fatty acids as secondary prevention against cardiovascular events in patients who undergo chronic hemodialysis: A randomized, placebo-controlled intervention trial. Clin. J. Am. Soc. Nephrol. 2006, 1, 780-786. [CrossRef] [PubMed]

87. Kutner, N.G.; Clow, P.W.; Zhang, R.; Aviles, X. Association of fish intake and survival in a cohort of incident dialysis patients. Am. J. Kidney Dis. 2002, 39, 1018-1024. [CrossRef] [PubMed]

88. Harris, W.S. Alpha-linolenic acid: A gift from the land? Circulation 2005, 111, 2872-2874. [CrossRef] [PubMed] 
89. Ren, J.; Chung, S.H. Anti-inflammatory effect of alpha-linolenic acid and its mode of action through the inhibition of nitric oxide production and inducible nitric oxide synthase gene expression via NF-kappa B and mitogen-activated protein kinase pathways. J. Agric. Food Chem. 2007, 55, 5073-5080. [CrossRef] [PubMed]

90. Su, H.; Liu, R.; Chang, M.; Huang, J.; Jin, Q.; Wang, X. Effect of dietary alpha-linolenic acid on blood inflammatory markers: A systematic review and meta-analysis of randomized controlled trials. Eur. J. Nutr. 2018, 57, 277-891. [CrossRef] [PubMed]

91. Zhang, K.; Liu, L.; Cheng, X.; Dong, J.; Geng, Q.; Zuo, L. Low levels of vitamin C in dialysis patients is associated with decreased prealbumin and increased C-reactive protein. BMC Nephrol. 2011, 12, 18. [CrossRef] [PubMed]

92. Deved, V.; Poyah, P.; James, M.T.; Tonelli, M.; Manns, B.J.; Walsh, M.; Hemmelgarn, B.R. Ascorbic acid for anemia management in hemodialysis patients: A systematic review and meta-analysis. Am. J. Kidney Dis. 2009, 54, 1089-1097. [CrossRef] [PubMed]

93. Sen, C.K.; Khanna, S.; Roy, S. Tocotrienols: Vitamin E beyond tocopherols. Life Sci. 2006, 78, $2088-2098$. [CrossRef] [PubMed]

94. Heng, E.C.; Karsani, S.A.; Abdul Rahman, M.; Abdul Hamid, N.A.; Hamid, Z.; Wan Ngah, W.Z. Supplementation with tocotrienol-rich fraction alters the plasma levels of Apolipoprotein A-I precursor, Apolipoprotein E precursor, and C-reactive protein precursor from young and old individuals. Eur. J. Nutr. 2013, 52, 1811-1820. [CrossRef] [PubMed]

95. Saboori, S.; Shab-Bidar, S.; Speakman, J.R.; Yousefi Rad, E.; Djafarian, K. Effect of vitamin E supplementation on serum C-reactive protein level: A meta-analysis of randomized controlled trials. Eur. J. Clin. Nutr. 2015, 69, 867-873. [CrossRef] [PubMed]

96. D’Arrigo, G.; Baggetta, R.; Tripepi, G.; Galli, F.; Bolignano, D. Effects of vitamin E-coated versus conventional membranes in chronic hemodialysis patients: A systematic review and meta-analysis. Blood Purif. 2017, 43, 101-122. [CrossRef] [PubMed]

97. Boaz, M.; Smetana, S.; Weinstein, T.; Matas, Z.; Gafter, U.; Iaina, A.; Knecht, A.; Weissgarten, Y.; Brunner, D.; Fainaru, M.; et al. Secondary prevention with antioxidants of cardiovascular disease in endstage renal disease (SPACE): Randomised placebo-controlled trial. Lancet 2000, 356, 1213-1218. [CrossRef]

98. Tonelli, M.; Wiebe, N.; Hemmelgarn, B.; Klarenbach, S.; Field, C.; Manns, B.; Thadhani, R.; Gill, J. Trace elements in hemodialysis patients: A systematic review and meta-analysis. BMC Med. 2009, 7, 25. [CrossRef] [PubMed]

99. Fujishima, Y.; Ohsawa, M.; Itai, K.; Kato, K.; Tanno, K.; Turin, T.C.; Onoda, T.; Endo, S.; Okayama, A.; Fujioka, T. Serum selenium levels in hemodialysis patients are significantly lower than those in healthy controls. Blood Purif. 2011, 32, 43-47. [CrossRef] [PubMed]

100. Zachara, B.A.; Koterska, D.; Manitius, J.; Sadowski, L.; Dziedziczko, A.; Salak, A.; Wasowicz, W. Selenium supplementation on plasma glutathione peroxidase activity in patients with end-stage chronic renal failure. Biol. Trace Elem. Res. 2004, 97, 15-30. [CrossRef]

101. Zachara, B.A.; Gromadzinska, J.; Zbrog, Z.; Swiech, R.; Wasowicz, W.; Twardowska, E.; Jablonska, E.; Sobala, W. Selenium supplementation to chronic kidney disease patients on hemodialysis does not induce the synthesis of plasma glutathione peroxidase. Acta Biochim. Pol. 2009, 56, 183-187. [PubMed]

102. Gomes, M.B.; Negrato, C.A. Alpha-lipoic acid as a pleiotropic compound with potential therapeutic use in diabetes and other chronic diseases. Diabetol. Metab. Syndr. 2014, 6, 80. [CrossRef] [PubMed]

103. Bucharles, S.; Barberato, S.H.; Stinghen, A.E.; Gruber, B.; Meister, H.; Mehl, A.; Piekala, L.; Dambiski, A.C.; Souza, A.; Olandoski, M.; et al. Hypovitaminosis D is associated with systemic inflammation and concentric myocardial geometric pattern in hemodialysis patients with low iPTH levels. Nephron Clin. Pract. 2011, 118, c384-c391. [CrossRef] [PubMed]

104. Matias, P.J.; Jorge, C.; Ferreira, C.; Borges, M.; Aires, I.; Amaral, T.; Gil, C.; Cortez, J.; Ferreira, A. Cholecalciferol supplementation in hemodialysis patients: Effects on mineral metabolism, inflammation, and cardiac dimension parameters. Clin J. Am. Soc. Nephrol. 2010, 5, 905-911. [CrossRef] [PubMed]

105. Ma, Y.; Griffith, J.A.; Chasan-Taber, L.; Olendzki, B.C.; Jackson, E.; Stanek, E.J., 3rd; Li, W.; Pagoto, S.L.; Hafner, A.R.; Ockene, I.S. Association between dietary fiber and serum C-reactive protein. Am. J. Clin. Nutr. 2006, 83, 760-766. [CrossRef] [PubMed]

106. North, C.J.; Venter, C.S.; Jerling, J.C. The effects of dietary fibre on C-reactive protein, an inflammation marker predicting cardiovascular disease. Eur. J. Clin. Nutr. 2009, 63, 921-933. [CrossRef] [PubMed] 
107. Xu, H.; Huang, X.; Riserus, U.; Krishnamurthy, V.M.; Cederholm, T.; Arnlov, J.; Lindholm, B.; Sjogren, P.; Carrero, J.J. Dietary fiber, kidney function, inflammation, and mortality risk. Clin. J. Am. Soc. Nephrol. 2014, 9, 2104-2110. [CrossRef] [PubMed]

108. McLoughlin, R.F.; Berthon, B.S.; Jensen, M.E.; Baines, K.J.; Wood, L.G. Short-chain fatty acids, prebiotics, synbiotics, and systemic inflammation: A systematic review and meta-analysis. Am. J. Clin. Nutr. 2017, 106, 930-945. [CrossRef] [PubMed]

109. Kalantar-Zadeh, K.; Kopple, J.D.; Deepak, S.; Block, D.; Block, G. Food intake characteristics of hemodialysis patients as obtained by food frequency questionnaire. J. Ren. Nutr. 2002, 12, 17-31. [CrossRef] [PubMed]

110. Calder, P.C.; Ahluwalia, N.; Albers, R.; Bosco, N.; Bourdet-Sicard, R.; Haller, D.; Holgate, S.T.; Jönsson, L.S.; Latulippe, M.E.; Marcos, A.; Moreines, J. A consideration of biomarkers to be used for evaluation of inflammation in human nutritional studies. Br. J. Nutr. 2013, 109 (Suppl. S1), S1-S34. [CrossRef] [PubMed]

2018 by the authors. Licensee MDPI, Basel, Switzerland. This article is an open access article distributed under the terms and conditions of the Creative Commons Attribution (CC BY) license (http:/ / creativecommons.org/licenses/by/4.0/). 